\title{
BODY MUSCLE MASS METABOLIC DATA ANALYSIS IN ASSOCIATION WITH CROHN'S DISEASE ACTIVITY
}

\author{
Polina Zaḷizko ${ }^{1,2,3, \#}$, Monta Urbāne ${ }^{1,3}$, Terēze Hermīne Roshofa ${ }^{3}$, Viktorija Mokricka ${ }^{1,2}$, \\ Laila Meija ${ }^{1,3}$, Edgars Bodnieks ${ }^{1,3}$, and Aldis Pukititis ${ }^{1,2}$ \\ 1 Pauls Stradiṇš Clinical University Hospital, 13 Pilsoṇu Str., Rīga, LV-1002, LATVIA \\ ${ }^{2}$ Faculty of Medicine, University of Latvia, 19 Raina Blvd., Rīga, LV-1586, LATVIA \\ ${ }^{3}$ Faculty of Medicine, Rīga Stradinš̌ University, 16 Dzirciema Str., Rīga, LV-1007, LATVIA \\ \# Corresponding author, polina.zalizko@stradini.Iv
}

Communicated by Dainis Krieviṇš

\begin{abstract}
Malnutrition is a common complication of Crohn's disease (CD) patients and it is correlated with alterations of the body composition and disease activity. Our prospective pilot study included hospitalised CD patients, age $\geq 18$ years. Patients were assessed using the Nutritional Risk Score (NRS2002), the Malnutrition Universal Screening Tool (MUST), and body bioelectrical impedance analysis. Twenty-three hospitalised patients (median age 36.5, interquartile range (IQR): 28.5-51.5 years) were enrolled; the median $C D$ activity index was 128 (IQR $=6.0-207.0)$. The study group comprised $48 \%(n=11)$ patients with low CD activity and $52 \%(n=12)$ with high disease activity. According to NRS2002 and MUST, 70\% $(n=16)$ CD patients had malnutrition risk and were in need of nutritional support. The median BMI was lower for the CD group $(21.10[I Q R=19.2-23.3])$ than for the control group $(23.4$ [IQR $=21.5-25.8])(\mathrm{p}=0.014)$. In terms of deviation from standard weight, $39 \%(n=9)$ of CD patients showed reduced \% body fat. Reduced muscle mass was observed in $48 \%(n=11)$ of CD patients. CD patients with high disease activity had a noticeably increased risk of malnutrition. Identification of the reduction in soft lean muscle mass in $C D$ patients can be used as an anticipatory indicator of disease activity.
\end{abstract}

Keywords: inflammatory bowel disease, Crohn's disease activity index, malnutrition, screening tools.

\section{INTRODUCTION}

Crohn's disease (CD) is a chronic inflammatory bowel disease (IBD) with periods of activity and remission (Ferre et al., 2018). In industrialised countries, IBD has become a global disease and the incidence of $C D$ has risen significantly over the past half century (Levine et al., 2020). The highest reported prevalence values were in Europe - 322 cases per 100000 (Ng, 2017). Smoking, use of antibiotics, and diet are potentially preventable risk factors for IBD (Forbes et al., 2017). CD commonly can lead to malnutrition, estimated in $65-75 \%$ of patients with CD (Scaldaferri et al., 2017), and specific nutritional deficiencies, which may be caused by low dietary intake, changes in metabolism, increased intestinal protein loss, and nutrient malabsorption (Jahnsen et al., 2003; Wędrychowicz et al., 2016). The nutritional status of IBD patients is frequently altered, even when the disease is in remission, although it is directly related to the severity of the disease (Back et al., 2017; Casanova et al., 2017).

Malnutrition is an objective disease activity parameter for patients with IBD, particularly $\mathrm{CD}$, and is an indicator of systemic damage or inflammatory activity. Active disease is correlated with the systemic response of the body's immune system, activating a hypermetabolic state and protein degradation, decreasing protein synthesis (Argiles et al., 2015). These conditions lead to malnutrition, which significantly increases the risk of impaired clinical outcomes, such as delayed recovery or increased mortality (Landi et al., 2019). Inadequate body composition and malnutrition have been associated with poor outcomes, such as a higher frequency of postoperative complications, longer hospital stays, decreased quality of life and higher health costs (Casanova et 
$a l ., 2017)$. The severity of malnutrition depends on the activity, duration and extent of the disease, and inflammatory response, which drives catabolism (Forbes et al., 2017).

To evaluate malnutrition, basic anthropometry techniques were used, such as body mass index (BMI) and biochemical parameters, but they are not accurate enough to estimate body composition. In a high proportion of IBD patients, these values may be within normal ranges, while they still have an altered body composition. Therefore, bioelectrical impedance analysis (BIA) is used to calculate total body water (TBW), and to estimate fat-free mass (FFM) [lean mass], muscle and fat mass (Casanova et al., 2017). BIA is easy, non-invasive, relatively inexpensive and can be performed in almost any subject because it is portable (Kyle, et al., 2004). Screening for malnutrition, using screening tools like the Nutritional Risk Screening Score 2002 (NRS2002) and Malnutrition Universal Screening Tool (MUST), which are recommended by the European Society of Clinical Nutrition and Metabolism, is important to identify subjects at nutritional risk (Kondrup et al., 2003). Referring to recommendations, screening should be performed within the first 24-48 h after first contact and thereafter at regular intervals. For those identified as being at risk by nutritional screening, nutritional assessment should be provided (Caderholm et al., 2017).

Recent studies have shown that between $22 \%$ and $60 \%$ of patients with IBD have FFM depletion. This is significant because FFM depletion has been associated with negative outcomes, including major postoperative complications predicting a small bowel resection, primary non-response to antitumor necrosis factor (TNF) agents, and osteopenia. Traditional nutritional measurements, like BMI, correlate poorly with indices of FFM in patients with $\mathrm{CD}$, resulting in a risk for under recognition and underestimation of the extent of nutrition depletion when relying only on weightbased indicators of nutritional status (Wood, 2020). Reduced muscle mass has been included in the Global Consensus for Diagnosing Malnutrition in Adult Patients (Cedeholm et al., 2019).

The aim of this study was to analyse body muscle mass metabolic data in association with Crohn's disease, identifying patients with low and high disease clinical activity.

\section{MATERIALS AND METHODS}

This prospective pilot study included twenty-three hospitalised patients aged $\geq 18$ years, with an established diagnosis of $\mathrm{CD}$ and no medical history of surgical interventions. $\mathrm{CD}$ patients were divided into those with low and high clinical activity indexes, according to the $\mathrm{CD}$ activity index (CDAI): low clinical activity index $(\mathrm{CDAI}<150)$ and high clinical activity index (CDAI > 150).

Patients were assessed twice using the Nutritional Risk Score (NRS2002) and Malnutrition Universal Screening Tool (MUST), recommended by the European Society of
Clinical Nutrition and Metabolism. The MUST has been found to have excellent inter-rater reliability, concurrent validity with other tools, and predictive validity (length of hospital stay and mortality). Its purpose is to identify individuals at risk of developing malnutrition based on nutrition status (BMI and weight loss) and disease-related dysfunction. NRS2002 contains the nutritional components of MUST, and in addition, a grading of severity of disease as a reflection of increased nutritional requirements; its purpose is to identify patients at risk of malnutrition within 48 hours after hospital admission and to determine those who would benefit from early nutrition therapy (Kondrup et al., 2003; Rabito et al., 2017).

Body bioelectrical impedance analysis (BIA) measurements were performed using impedance equipment at least three hours after eating, as this may reduce small errors in impedance determination (Kyle et al., 2004). The whole body was measured, by subdividing it into various segments. Furthermore, weight (kg), BMI, fat-free mass (FFM) (kg), soft lean mass (SLM) $(\mathrm{kg})$, metabolic body fat $(\mathrm{MBF})(\mathrm{kg})$, total body water $(\mathrm{TBW})(\mathrm{kg})$, basal metabolic rate (kcal), total energy expenditure (kcal), visceral fat $(\%)$, and per cent body fat (PBF) were assessed.

A control group consisting of twenty-three healthy age- and sex-matched individuals was used for comparison. BIA was performed if the person met the inclusion criteria: age $\geq 18$ years old and age-matched to the patient group, with no food intake $\geq 3$ hours prior to testing, and with no nutritional risks identified using both screening tools (NRS2002 and MUST), which assured that the control group did not harbour any active disease that would interfere with the study results.

Statistical analysis was performed using SPSS version 22 (IMDB Statistical Package for the Social Sciences 22). Statistical significance was set at $p$-values $\leq 0.05$. The study was performed in accordance with the Declaration of Helsinki and was approved by the Medical Ethics Committee.

\section{RESULTS}

Twenty-three hospitalised patients (median age 36.5, interquartile range (IQR): 28.5-51.5 years) were enrolled, 39\% $(\mathrm{n}=9)$ were female and $61 \%(\mathrm{n}=14)$ male. The median CDAI was 128 (IQR = 6.0-207.0). The study group comprised $48 \%(\mathrm{n}=11)$ patients with low $\mathrm{CD}$ activity and $52 \%$ $(\mathrm{n}=12)$ of patients with high disease activity (Fig. 1).

According to NRS2002 and MUST, 70\% ( $\mathrm{n}=16)$ CD patients were nutritionally at risk and in need of nutritional support. From twelve patients with high disease activity, $92 \%(\mathrm{n}=11)$ had a risk of malnutrition, and from eleven patients with low disease activity, only $45 \%(\mathrm{n}=5)$ has a risk of malnutrition $(p=0.027)$. Clinical nutrition was administered to 11 patients; enteral oral feeding was prescribed to nine of these patients. Additionally, two patients received parenteral peripheral feeding. 


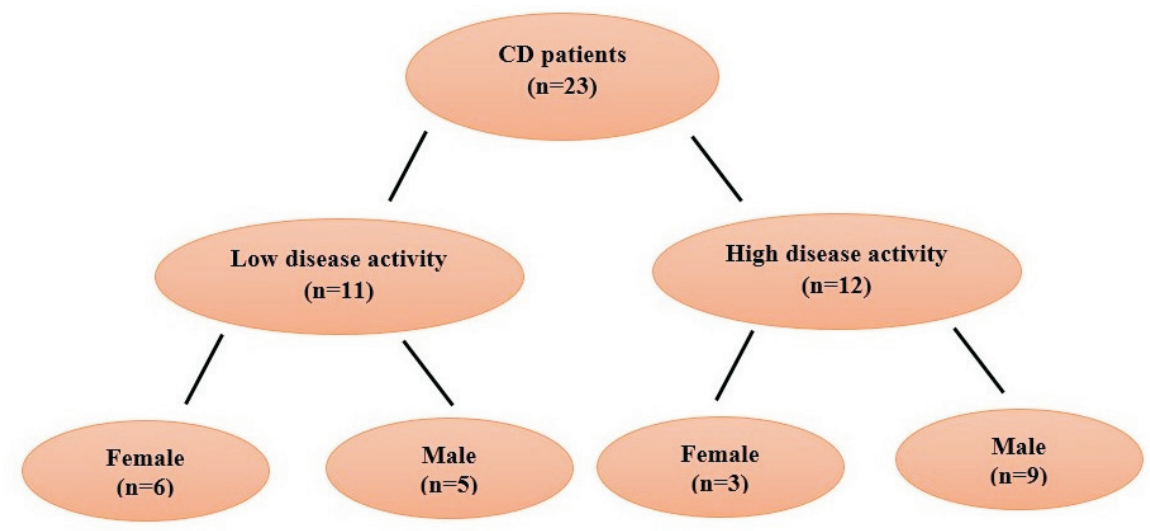

Fig. 1. Diagram of study flow.

Table 1. Comparison of parameters between Crohn's disease patients and the control group

\begin{tabular}{|c|c|c|c|}
\hline Parameters & $\mathrm{CD}$ patients & Control group & $p$-value \\
\hline Weight (kg) & $68.7 \pm 14.8$ & $73.5 \pm 13.9$ & 0.232 \\
\hline $\operatorname{PBF}(\%)$ & $21.3 \pm 7.5$ & $21.8 \pm 9.9$ & 0.355 \\
\hline Muscle mass deviation from normal & $0.6 \pm 3.1$ & $2.9 \pm 4.6$ & 0.143 \\
\hline Fat deviation from normal & $1.3 \pm 6.8$ & $1.8 \pm 5.0$ & 0.122 \\
\hline Muscle mass & $49.6[41.1-57.3]$ & $55.8[42.9-61.4]$ & 0.425 \\
\hline Proteins & $38.7[32.2-44.4]$ & $12.5[9.6-13.8]$ & $<0.001$ \\
\hline Minerals & $3.8[3.4-4.7]$ & $4.3[3.6-4.7]$ & 0.212 \\
\hline TBW & $38.7[32.20-44.35]$ & $43.1[33.4-47.4]$ & 0.454 \\
\hline Basal metabolism & 1503.0 [1196.00-1607.0] & 1518.5 [1266.5-1711.8] & 0.407 \\
\hline Weight deviation from normal & $4.1[-8.4-6.3]$ & $4.2[-1.2-12.2]$ & 0.102 \\
\hline BMI & $23.4[19.2-23.3]$ & $21.1[21.5-25.8]$ & 0.014 \\
\hline Visceral fat $\%$ & $-4.0[-12.1-5.6]$ & $7.9[-0.9-18.2]$ & 0.003 \\
\hline
\end{tabular}

BMI, body mass index; CD, Crohn's Disease; PBF, percent body fat; TBW, total body water

Data obtained by BIA was compared between the study group to those of the population control group (Table 1). Statistically important differences were observed in BMI, \% visceral fat and proteins. Other values also seemed to vary, but analysis did not show statistically significant differences. The albumin level was determined for17 patients, of whom $24 \%(n=4)$ had a reduced albumin level $(<3.5 \mathrm{~g} / \mathrm{dl})$ at the moment of admission.

Comparing BIA results between CD patients and the control group, the median BMI was significantly lower for the CD (21.10 [IQR $=19.2-23.3])$ than for the control group (23.4 $[\mathrm{IQR}=21.5-25.8])(p=0.014)$. In addition, visceral fat mass was significantly lower in the CD $(-4.00$ [IQR $=-12.1$ to 5.6]) than in the control group (7.85 [IQR $=-0.9-18.2])$ $(p=0.003)$. An imbalanced body composition with changes in PBF and SLM was observed in a large proportion of patients. In terms of deviation from standard weight, 39\% $(\mathrm{n}=$ 9) of CD patients showed reduced PBF. This indicated that even though patients had BMI within normal values, there was a high chance of having imbalance in body composition. Reduced muscle mass was observed in $48 \%(n=11)$ of $\mathrm{CD}$ patients. $\mathrm{CD}$ patients were more prone to reduction in muscle mass when disease activity is high. Only a few individuals of the control group had muscle mass under the normal values.

\section{DISCUSSION}

In our study, according to NRS2002 and MUST, 70\% CD patients were nutritionally at risk and in need of nutritional support. In a previous study (Stratton et al., 2004) using MUST, the prevalence of malnutrition risk ranged from $19-60 \%$ in inpatients and $30 \%$ in outpatients. Our results were higher, which can be explained by higher disease activity and probably with various nutritional and metabolic disturbances. Our data indicated strong agreement between both scales on evaluation of the nutritional status of the patient. Similar agreement has also been reported (Stratton et al., 2004), where MUST had excellent agreement (k 0.775-0.893) with MEREC, NRS and SGA tools).

Those identified to be at risk of malnutrition by using malnutrition screening tools, should be followed by nutritional assessment, which will give the basis for the diagnosis, as well as for further action including nutritional treatment. Assessment of the nutritional status integrates information on body weight, body height, body mass index $\left(\mathrm{kg} / \mathrm{m}^{2}\right)$, body composition and biochemical indices (Cederholm et al., 2017).

Malnutrition is defined as a subacute or chronic state in which a combination of negative energy balance and varying degrees of inflammatory activity has led to changed 
body composition, diminished function, and adverse outcomes (Cederholm et al., 2017). Malnutrition adversely affects physical and psychological function and impairs a patients recovery from disease and injury, thereby increasing morbidity and mortality. Despite being a common problem, malnutrition is frequently unrecognised and untreated in many health care settings, including nursing and other care homes, general practice, and hospital outpatients and inpatients (Stratton et al., 2004).

It has been reported that ileal involvement in $\mathrm{CD}$ patients plays a relevant role in reducing nutrient absorption (Balestrieri et al., 2020). Nutritional deficiencies are self-evidently more likely in patients with $\mathrm{CD}$ affecting the small bowel than in those with isolated colonic disease (Forbes et al., 2017).

The severity of malnutrition is dependent on the activity, duration, and extent of the disease and, in particular, on the magnitude of the inflammatory systemic response mediated by pro-inflammatory cytokines such as tumour necrosis factor (TNF)- $\alpha$ and interleukins- 1 and -6 , which can increase catabolism and lead to anorexia (Balestrieri et al., 2020). In our study it was confirmed that patients with higher disease activity has a higher risk of malnutrition. From twelve patients with high disease activity, 92\% $(n=11)$ had a risk of malnutrition, and from eleven patients with low disease activity, only $45 \%(n=5)$ had a risk of malnutrition. This difference was statistically significant $(p=0.027)$.

Detection of reduced body muscle mass has emerged as a crucial variable in nutritional assessment. A progressive and general loss of lean muscle mass associated with decreased muscle strength or physical performance has significant impact on the quality of life and causes physical disability (Balestrieri et al., 2020). A systematic review (Ryan et al., 2019) reported that up to $60 \%$ IBD patients have decreased muscle mass when compared with healthy subjects and a higher percentage were patients with $\mathrm{CD}$ and these patients were more likely to be male (Ryan et al., 2019). In our study, reduced muscle mass was observed in $48 \%$ of CD patients and $39 \%$ were men. Low lean mass is likely a surrogate marker of ill-health and inadequately controlled disease activity, and may be associated with fatigue and reduced quality of life in patients with IBD. Some studies have shown that BMI does not correlate well with lean mass in patients with IBD, even amongst those in clinical remission. Increase of BMI may be related to gain in fat mass, further masking the underlying lean mass deficit. BMI was shown to better correlate with fat mass than with lean mass. In fact, a normal BMI was falsely reassuring in $72 \%$ of patients who were demonstrated to have low lean mass (Bryant et al., 2015).

According to the World Health Organisation standardised criteria, patients were considered to be well-nourished when their BMI was between 18.5 and $24.5 \mathrm{~kg} / \mathrm{m}^{2}$, underweight or malnourished when their BMI was $\leq 18.5 \mathrm{~kg} / \mathrm{m}^{2}$, and overweight when their BMI was $\geq 25 \mathrm{~kg} / \mathrm{m}^{2}$. According our results, BMI was decreased only in three patients. There- fore, the evaluation of BIA parameters is important. Evidence shows that reduced muscle mass can also be related to an unchanged or even elevated BMI (Balestrieri et al., 2020). Therefore, it is important to assess those who are not visibly malnourished.

In systematic review (Ryan et al., 2019), it was reported that the serum albumin concentration was significantly lower in patients with CD compared with controls $(2.6 \mathrm{~g} / \mathrm{dl}$ vs $3.0 \mathrm{~g} / \mathrm{dl} ; p=0,002)$. In another review (Zhang et al., 2017) the estimated mean albumin concentration for patients at high risk of malnutrition (detected by NRS-2002) was 3.42 (95\% CI: 3.19, 3.64). This indicates that using albumin with a cut-off of $3.5 \mathrm{~g} / \mathrm{dl}$ would fail to identify a proportion of the patients diagnosed to be at high risk of malnutrition using NRS-2002, not to mention those at low malnutrition risk. In our study, from seventeen patients for whom the albumin level was determined, only four patients had a reduced albumin level $(<3.5 \mathrm{~g} / \mathrm{dl})$. Therefore, the significance of serum albumin as an indicator of nutritional status is controversial, because the serum albumin level is affected by intravenous fluids and dehydration (Takaoka et al., 2018).

Monitoring of anthropometry provides insight into which patients develop relative deficits in lean mass and therefore would benefit from nutritional supplementation. The protein requirement is increased in active disease, and intake should be increased, but in remission the protein requirements are generally not elevated and provision should be similar to that recommended in the general population. In general, no specific diet needs to be followed during remission phases (Forbes et al., 2017).

Nutrition or nutrients can be provided orally, via enteral tube-feeding or as parenteral nutrition to prevent or treat malnutrition in an individualised way (Cederholm et al., 2017). The nutritional care plan is based on the results of the assessment. This plan should be developed by a multi/interdisciplinary team together with the patient. In our study, nine patients received enteral and two patients parenteral feeding that was individualised for each patient based on nutritional assessment results.

\section{CONCLUSION}

CD patients with high disease activity had a noticeably increased risk of malnutrition. $48 \%$ of CD patients in both the low and high disease activity groups had a reduction in muscle mass. Identification of the reduction in soft lean muscle mass in CD patients can be used as an indicator of disease activity.

\section{REFERENCES}

Argilés, J. M., Busquets, S., Stemmler, B., López-Soriano, F. J. (2015). Cachexia and sarcopenia: Mechanisms and potential targets for intervention. Curr. Opin. Pharmacol., 22, 100-106. 
Back, I. R., Marcon, S. S., Gaino, N. M., Vulcano, D. S. B., Dorna, M. S., Sassaki, L. Y. (2017). Body composition in patients with Crohn's disease and ulcerative colitis. Arq. Gastroenterol., 54 (2), 109-114.

Balestrieri, P., Ribolsi, M., Guarino, M. P. L., Emerenziani, S., Altomare, A., Cicala, M. (2020). Nutritional aspects in inflammatory bowel diseases. Nutrients, 12 (2), 372.

Bryant, R. V., Ooi, S., Schultz, C. G., Goess, C., Grafton, R., Hughes, J., Lim, A., Bartholomeusz, F. D., Andrews, J. M. (2015). Low muscle mass and sarcopenia: Common and predictive of osteopenia in inflammatory bowel disease. Aliment Pharmacol. Ther. Actions, 41 (9), 895-906.

Casanova, M. J., Chaparro, M., Molina, B., Merino, O, Batanero, R., Duenas-Sadornil, C., Robledo, P., Garcia-Albert, A. M., Gomez-Sanchez, M. B., Calvet, X., et al. (2017). Prevalence of malnutrition and nutritional characteristics of patients with inflammatory bowel disease. J. Crohns. Colitis, 11 (12), 1430-1439.

Cederholm, T., Barazzoni, R., Austin, P., Ballmer, P., Biolo, G., Bischoff, S. C., Compher, C., Correia, I., Higashiguchi, T., Holst, M., et al. (2017). ESPEN guidelines on definitions and terminology of clinical nutrition. Clin. Nutr., 36 (1), 49-64.

Ferré, M. P. B., Boscá-Watts, M. M., Pérez, M. M. (2018). Crohn's disease. Med. Clin. (Barc)., 151 (1), 26-33.

Forbes, A., Escher, J., Hébuterne, X., Kłęk, S., Krznaric, Z., Schneider, S., Shamir, R., Stardelova, K., Wierdsma, N., Wiskin, A. E., Bischoff, S. C. (2017). ESPEN guideline: Clinical nutrition in inflammatory bowel disease. Clin. Nutr., 36 (2), 321-347.

Jahnsen, J. Falch, J. A., Mowinckel, P., Aadland, E. (2003). Body composition in patients with inflammatory bowel disease: A population-based study. Amer. J. Gastroenterol., 98 (7), 1556-1562.

Kondrup J., Allison, M., Elia, M., Vellas, B., Plauth, M. (2003). ESPEN Guidelines for Nutrition Screening. Clin. Nutr., 22 (4), 415-421.

Kyle, U. G., Bosaeus, I., De Lorenzo, A. D., Deurenberg, P., Elia, M., Gómez, J. M., Heitmann, B. L., Kent-Smith, L., Melchior, J. C., Pirlich, M., Scharfetter H. (2004). Bioelectrical impedance analysis. Part II: Utilization in clinical practice. Clin. Nutr., 23 (6), 1430-1453.

Landi, F., Camprubi-Robles, M., Bear, D. E., Cederholm, T., Malafarina, V., Welch, A. A., Cruz-Jentoft, A. J. (2019). Muscle loss: The new malnutrition challenge in clinical practice. Clin. Nutr., 38 (5), 2113-2120.
Levine, J. S., Burakoff, R. (2016). Inflammatory bowel disease: Medical considerations. In: Greenberger, N. J., Blumberg, R. S., Burakoff, R. (eds.). Current Diagnosis \& Treatment: Gastroenterology, Hepatology \& Endoscopy. $3^{\text {rd }}$ edition. McGraw-Hill. $656 \mathrm{pp}$.

Ng, S. C., Shi, H. Y., Hamidi, N., Underwood, F. E., Tang, W., Benchimol, E. I., Panaccione, R., Ghosh, S., Wu, J. C., Chan, F. K. L., Sung, J. J. Y., Kaplan, G. G. (2018). Worldwide incidence and prevalence of inflammatory bowel disease in the 21st century: A systematic review of population-based studies. Lancet, 390 (10114), 2769-2778.

Rabito, E. I., Marcadenti, A., Fink, J. S., Figueira, L., Silva, F. M. (2017). Nutritional risk screening 2002, Short Nutritional Assessment Questionnaire, Malnutrition Screening Tool, and Malnutrition Universal Screening Tool are good predictors of nutrition risk in an emergency service. Nutr. Clin. Pract., 32 (4), 526-532.

Ryan, E., McNicholas, D., Creavin, B., Kelly, M. E., Walsh, T., Beddy D. (2019). Sarcopenia and inflammatory bowel disease: A systematic review. Inflamm. Bowel Dis., 25 (1), 67-73.

Scaldaferri F., Pizzoferrato M., Lopetuso L.R., Musca T., Ingravalle F., Sicignano L.L., Mentella M., Miggiano G., Mele M.C., Gaetani E., et al. (2017). Nutrition and IBD: Malnutrition and/or sarcopenia? A practical guide. Gastroenterol. Res. Pract., 2017, 8646495.

Stratton, R. J., Hackston, A., Longmore, D., Dixon, R., Price, S., Stroud, M., King, C., Elia, M. (2004). Malnutrition in hospital outpatients and inpatients: Prevalence, concurrent validity and ease of use of the 'malnutrition universal screening tool' ('MUST') for adults. Brit. J. Nutr., 92 (5), 799-808.

Takaoka, A., Sasaki, M., Nakanishi, N., Kurihara, M., Ohi, A., Bamba, S., Andoh, A. (2018). Nutritional screening and clinical outcome in hospitalized patients with Crohn's disease. Ann. Nutr. Metab., 71, 266-272.

Wędrychowicz, A., Zając, A., Tomasik P. (2016). Advances in nutritional therapy in inflammatory bowel diseases: Review. World J. Gastroenterol., 22 (3), 1045-1066.

Wood, J., Ward, L., Sparrow, M., King, S. (2020). Utility of bioimpedance methods for the assessment of fat-free mass in adult outpatients with inflammatory bowel disease. Nutrition, 77, 110833.

Zhang, Z., Pereira, S. L., Luo, M., Matheson, E. M. (2017). Evaluation of blood biomarkers associated with risk of malnutrition in older adults: A systematic review and meta-analysis. Nutrients, $9(8), 829$.

\section{KERMEN̦A MUSKUḶU MASAS METABOLO RĀDĪTĀJU ANALĪZE SAISTĪBĀ AR KRONA SLIMĪBAS AKTIVITĀTI}

Krona slimība ir hroniska iekaisīga zarnu slimība ar slimības aktivitātes un remisijas periodiem. Iekaisīgas zarnu slimības ir kḷuvušas par globālu problēmu. Krona slimības izplatība ievērojami pieaugusi pēdējo gadu laikā. Malnutrīcija ir bieži sastopama komplikācija Krona slimības pacientiem. Tā korelē ar slimības aktivitāti un izmain̄ām ḳermeṇa kompozīcijā. Pārmainas ḳermeṇa kompozīcijā saistītas ar biežākām pēcoperācijas komplikācijām, ilgāku hospitalizāciju, samazinātu dzīves kvalitāti un augstākām veselības aprūpes izmaksām. Šī pētījuma mērķis bija analizēt k̦ermeņa muskuļu masas vielmaiņas radīiāju saistību ar Krona slimību un zemu vai augstu slimības aktivitāti. Pētỉjumā iekḷauti 23 hospitalizēti Krona slimības pacienti vecumā $\geq 18$ gadi. Pacienti tika novērtēti divas reizes, izmantojot malnutrīcijas skrīninga skalas Nutritional Risk Score (NRS 2002) un Malnutrition Universal Screening Tool (MUST), kā arī tika veikta kermeña bioelektriskās impedances analīze. Pētījumā novērots, ka pacientiem ar augstu slimības aktivitāti bija ievērojami augstāks malnutrīcijas risks. Lielai daḷi (48\%) Krona slimības pacientu gan ar zemu, gan augstu slimības aktivitāti bija samazināta muskuḷ masa. Muskuḷ masas samazinājuma noteikšanu Krona slimības pacientiem var pielietot kā slimības aktivitātes rādīiāju. Pētījumā konstatēts, ka ne tikai pacientiem ar samazinātu ķermeņa masas indeksu (K,MI), bet arī pacientiem ar normālu vai paaugstinātu ĶMI ir augsts ķermeņa kompozīcijas izmainu risks. 